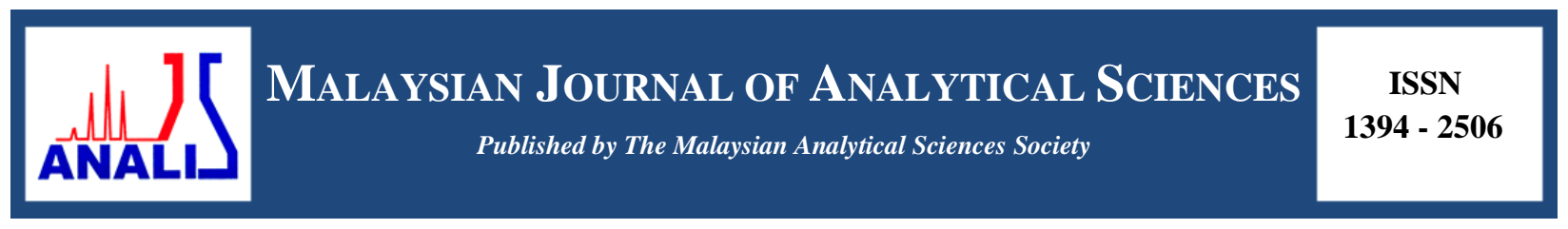

\title{
BIOMONITORING OF HEAVY METALS USING INTERTIDAL MOLLUSKS IN EAST JOHOR COASTAL WATERS
}

\author{
(Biopemerhatian Logam Berat Menggunakan Moluska Intertidal di Perairan Pantai Johor Timur) \\ Mohd Mokhlesur Rahman ${ }^{1}$, Fuad Miskon ${ }^{2}$, Kamaruzzaman Yunus $^{2}$, Noor Azhar M. Shazili ${ }^{3}$ \\ ${ }^{1}$ Department of Pharmacy, Faculty of Pharmacy \\ ${ }^{2}$ Department of Biotechnology, Faculty of Science \\ International Islamic University Malaysia, 25200 Kuantan, Pahang, Malaysia \\ ${ }^{3}$ School of Marine and Environmental Sciences, \\ Universiti Malaysia Terengganu, 21030 Kuala Terengganu, Terengganu \\ *Corresponding author: mdrahman@iium.edu.my
}

Received: 9 December 2014; Accepted: 6 April 2016

\begin{abstract}
Interspecies, inter-tissue and interspatial dissimilarities of trace metals in particular body parts of Saccostrea cucullata, Thais clavigera and Nerita chameleon from the east Johor coastal waters were compared. Metals of interest includes $\mathrm{Pb}, \mathrm{Cd}, \mathrm{Zn}, \mathrm{Cu}$, $\mathrm{Mn}, \mathrm{Co}, \mathrm{Se}$ and Sr. Bivalve mollusk S. cucullata evidenced to be a worthy bioindicator for $\mathrm{Zn}$ and $\mathrm{Cu}$ while the two gastropod molluscs, T. clavigera for $\mathrm{Cd}$ and $\mathrm{Se}$, and $N$. chameleon for $\mathrm{Pb}, \mathrm{Mn}$ and $\mathrm{Sr}$. The prominent concentration of metals originate in $T$. clavigera may be the outcome of biomagnification transfer from the S. cucullata on which they feed while for $N$. chameleon, it might be resulting from their herbivorous feeding behavior on algae on rocks which they graze. The metal accumulation patterns indicate consistent enrichment of essential metals in soft tissue. Values of operculum to tissue ratio (OTR) and shell to tissue (STR) higher than unity in T. clavigera indicate that operculum had higher affinities for $\mathrm{Pb}, \mathrm{Mn}$ and Se while shell had higher affinities for Co and Sr. In N. chameleon, values of OTR and STR higher than unity displayed that operculum and shell had similar higher affinities for $\mathrm{Co}$ and $\mathrm{Sr}$ and $\mathrm{Cd}$, $\mathrm{Co}$ and $\mathrm{Sr}$, respectively. Significant interspatial variations $(p<0.05$ and $p<0.01)$ in trace metals were noted. Assessment of metal concentration with maximum permissible limits of toxic metals in food shown the values were well within safety levels, except for $\mathrm{Zn}$ in $S$. cucullata that need to be monitored.
\end{abstract}

Keywords: heavy metals, intertidal mollusks, body parts, safety level

\begin{abstract}
Abstrak
Perbezaan logam surih antara spesis, antara tisu dan antara kawasan dalam bahagian badan tertentu Saccostrea cucullata, Thais clavigera dan Nerita chameleon dari perairan pantai Johor timur telah dikaji. Logam yang menjadi perhatian termasuklah $\mathrm{Pb}, \mathrm{Cd}$, $\mathrm{Zn}, \mathrm{Cu}, \mathrm{Mn}, \mathrm{Co}, \mathrm{Se}$ dan Sr. Moluska bivalvia S. cucullata terbukti berpotensi menjadi bioindikator bagi $\mathrm{Zn}$ dan $\mathrm{Cu}$ manakala kedua-dua moluska gastropoda, T. clavigera bagi $\mathrm{Cd}$ dan $\mathrm{Se}$, dan $N$. chameleon bagi $\mathrm{Pb}$, Mn dan Sr. Kepekatan logam yang menonjol dari $T$. clavigera kemungkinan terhasil dari pemindahan biomagnifikasi dari S. cucullata yang dimakan manakala bagi $N$. chameleon, ia berkemungkinan terhasil dari tabiat pemakanan secara herbivor ke atas alga di atas batu. Corak pengumpulan logam menunjukkan kepekatan logam perlu yang konsisten dalam tisu lembut. Nilai ratio operculum kepada tisu (OTR) dan ratio kulit ke tisu (STR) lebih tinggi dari paduan dalam $T$. clavigera menunjukkan operculum mempunyai affiniti yang tinggi bagi $\mathrm{Pb}$, Mn dan Se manakala kulit pula mempunyai affiniti yang tinggi bagi Co dan Sr. Dalam N. chameleon, nilai OTR dan STR lebih tinggi dari paduan menggambarkan bahawa operculum dan kulit mempunyai persamaan affiniti yang tinggi bagi Co dan $\mathrm{Sr}$ dan $\mathrm{Cd}$, Co dan Sr, masing-masing. Variasi antara kawasan yang signifikan $(p<0.05$ and $p<0.01)$ dalam logam surih telah dicatatkan. Pemeriksaan kepekatan logam dengan tahap maksimum yang dibenarkan bagi logam berat menunjukkan nilai masih lagi di bawah tahap selamat, kecuali Zn dalam S.cucullata yang perlu diberi perhatian.
\end{abstract}




\section{Mohd Mokhlesur et al: BIOMONITORING OF HEAVY METALS USING INTERTIDAL MOLLUSKS IN \\ EAST JOHOR COASTAL WATERS}

Kata kunci: logam berat, intertidal moluska, bahagian badan, had selamat

\section{Introduction}

Heavy metals in the aquatic system can be naturally formed by the slow leaching from soil to water, typically at low levels in the parts per billion ranges and producing serious effects on social health [1]. They remains in solution for a long time before being removed to the sediments of the sea floor, a route of reverse weathering, which removal mechanisms consist of inorganic precipitation and reactions between dissolved materials and solid particles, as well as biological process like bioaccumulation of bacteria and phytoplankton and larger organisms [2]. Although many metals were recognized to have vital biological roles in low concentration, e.g. $\mathrm{Cu}, \mathrm{Zn}, \mathrm{Mn}$, Fe; all these elements have the potential to be toxic to certain organisms above threshold concentration. Specific metal might alter into the persistent force of the metallic compounds with high toxicity, which leads to bioaccumulation in the organism's body, being magnified in the food chain and eventually threatening social health.

Much attention has been paid to the capability of marine organisms, especially molluscs to accumulate metallic toxicants from the marine environment where it lives. Goldberg [3] was the first to initiate the "Mussel Watch Program" in which the bivalves were used as a surveillance tool of coastal pollution. Biomonitoring is a scientific technique in evaluating environment health based on sampling and analysis of an individual organism's tissue and fluids. This method, which comprises human contacts to natural and synthetic chemicals, takes advantage of the facts that chemicals that have entered the organisms leave indicators reflecting this exposure. Compared with other invertebrate groups like arthropods and especially vertebrates, molluscs exhibit only a limited ability to excrete pollutants directly via their kidneys or other excretory organs and tissues, to metabolize organic chemicals, and physiologically to inactivate toxic heavy metals such as by the formation of and binding to metallothioneins [4]. As a consequence, molluscs achieve higher bioaccumulation factors for many toxicants than other groups. Observing of heavy metal contamination and bioavailabilities by the diverse parts of molluscs is remarkable since it might lessen the imprecisions of defining the heavy metal levels by using the total soft tissues [5].

The use of bioindicator organisms to study heavy metal pollution in the Malaysian environment has acknowledged extensive attention. Bivalves and gastropod were frequently used by a number of researchers while fishes were primarily used for health concern related to fish consumption by human. Since the molluscs are accessible along the coastal areas of Peninsular Malaysia and are easily collected, it can therefore be suggested to be good monitoring agents for chemicals pollution. The objectives of this study were to discover the heavy metals bioavailability in selected body parts of $S$. cucullata, $T$. clavigera and $N$. chameleon from rocky shore sites along the coastal waters of the east Johor and to provide an insight in their safety levels for human and environment monitoring. Data of $S$. cucullata was acquired from a study by Fuad et al. [6] for comparison.

\section{Study Area}

\section{Materials and Methods}

Table 1 and Figure 1 displayed map of sampling locations, coordinates and species collected for this study. Five sampling sites with the abundant numbers of $S$. cucullata, $T$. clavigera and $N$. chameleon population on natural rocky structures were sampled. Not all species were present in sufficient numbers at all sites. Samples of relatively same size were hand collected during low tide. All samples were placed in plastic bags, sealed, labeled and stored at $4-6{ }^{\circ} \mathrm{C}$ during transportation to the laboratory where the samples were rinsed with running Mili-Q water (18.2 $\Omega$ ) to remove sediment and salt particles prior to store frozen.

After allometric parameter measurement and tissue extraction, extracted tissues were freeze-dried before being weighed again in order to evaluate the water content and conversion factor. Freeze-dried samples were then minced to a homogenous powder and kept at room temperature until analysis. Please note that only soft tissue was extracted from rock oyster.

The analytical procedure was based on Shazili et al. method [7] with little modification. Measurement was carried out using Inductive Coupled Plasma Mass Spectrometry (ICP-MS) Elan 9000 in its standard configuration. Results 
were quantified via an external calibration curve generated from the responses obtained from multiple dilutions of a multi-element calibration standard that was prepared from multi-element standards stock solution (Merck). The results were blank corrected and expressed as $\mu \mathrm{g} \mathrm{g}^{-1}$ dry weight. Glassware used was immersed in $10 \%$ nitric acid $\left(\mathrm{HNO}_{3}\right)$ solution in advance for contamination prevention.

Table 1. Sampling locations, coordinates and species collected from east Johor coastal waters

\begin{tabular}{|c|c|c|c|}
\hline No & Sampling location & Coordinate & Species collected \\
\hline 1 & Sungai Rengit & $\mathrm{N} 01^{0} 20.985^{\prime}$, E $104^{0} 13.256^{\prime}$ & S. cucullata, $T$. clavigera, $N$. chameleon \\
\hline 2 & Batu Layar & $\mathrm{N} 01^{0} 26.673^{\prime}$, E $104^{0} 17.673^{\prime}$ & S. cucullata, N. chameleon \\
\hline 3 & Tanjung Balau & $\mathrm{N} 01^{0} 36.794^{\prime}$, E $104^{0} 15.558^{\prime}$ & S. cucullata, T. clavigera, $N$. chameleon \\
\hline 4 & Sedili Kechil & $\mathrm{N} 01^{0} 50.617^{\prime}$, E $104^{0} 08.957^{\prime}$ & S. cucullata, T. clavigera, $N$. chameleon \\
\hline 5 & Mersing & $\mathrm{N} 02^{0} 25.764^{\prime}$, E $103^{0} 50.870^{\prime}$ & S. cucullata, T. clavigera, $N$. chameleon \\
\hline
\end{tabular}

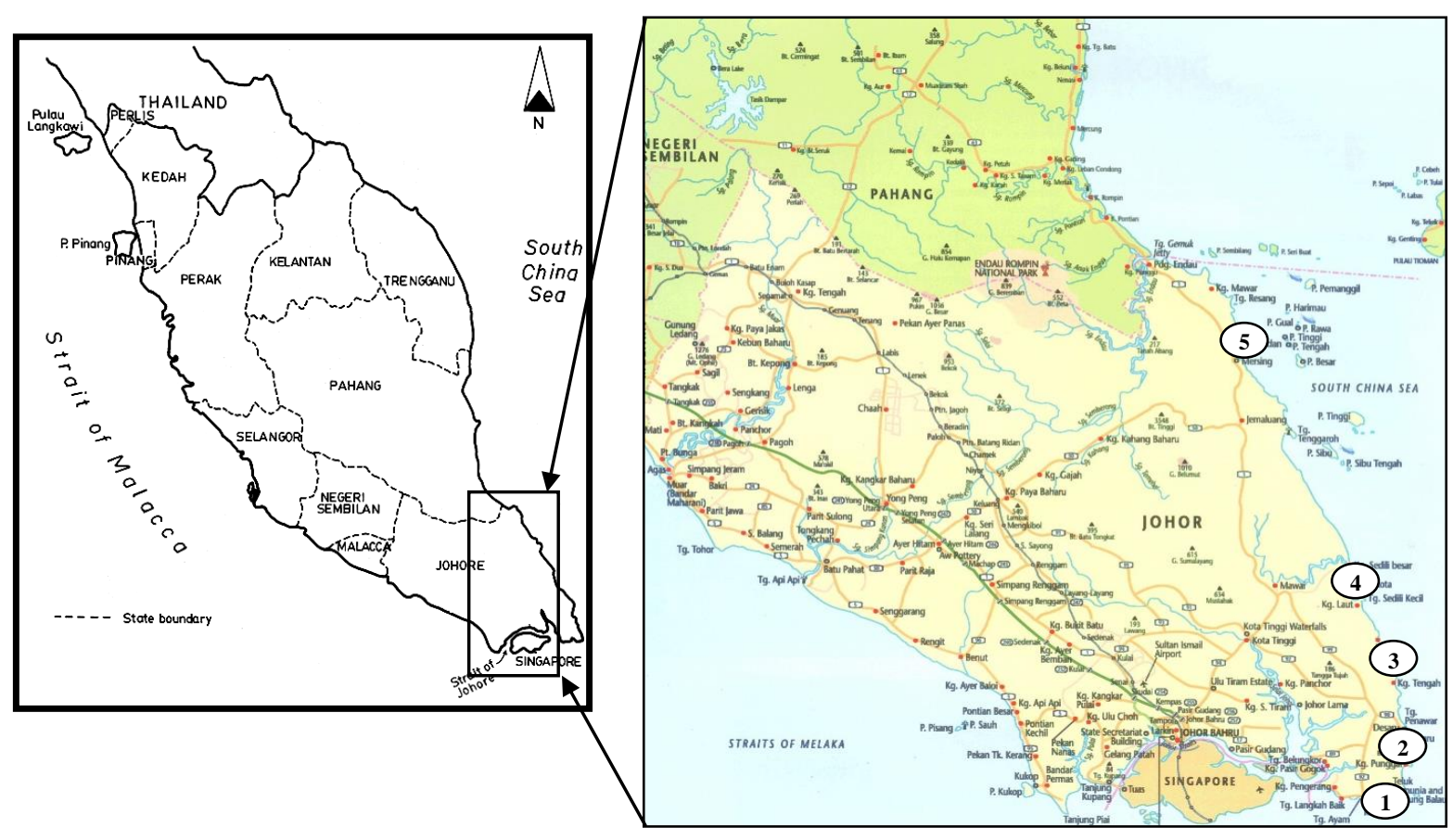

Figure 1. Map showing sampling locations at east Johor coastal waters. Sites are specified in Table 1

The quality of method used was confirmed in a separate comparative study using a standard reference material, Lobster Hepatopancreas TORT-2. Recoveries were as follows: $113.57 \%(\mathrm{~Pb}), 97.31 \%(\mathrm{Cd}), 85.56 \%(\mathrm{Cu}), 86.54$ $\%(\mathrm{Zn}), 81.80 \%(\mathrm{Mn}), 96.53 \%(\mathrm{Co}), 88.59 \%(\mathrm{Se})$ and $82.60 \%(\mathrm{Sr})$. One-way ANOVA was employed among assessment of variation between content of analyzed metals concentration in different sites. All comparisons were made at least at the $95 \%(p<0.05)$ and $99 \%(p<0.01)$ level of significance

\section{Results and Discussion}

The different studied species within the same location and the same species from different locations showed variations in their ability to concentrate trace elements. A comparison among species indicates that even closely 


\section{Mohd Mokhlesur et al: BIOMONITORING OF HEAVY METALS USING INTERTIDAL MOLLUSKS IN EAST JOHOR COASTAL WATERS}

related species from the same location might have significantly different accumulated element concentrations as well as interspatial variability. The fact that sampled organisms inhabits common localities but different feeding behavior indirectly shows a function of the preferences for a certain size and nature of food particles and the detoxifying mechanism that each species has. The differences in accumulation of the metals may arise from speciesspecific feeding habits as uptake of metals via food plays an important role.

According to Table 2, there are significant differences in concentrations of $\mathrm{Pb}, \mathrm{Cd}, \mathrm{Cu}, \mathrm{Zn}, \mathrm{Mn}, \mathrm{Co}$ and $\mathrm{Se}$ among sampling locations $(p<0.05)$ but no significant differences were found for $\operatorname{Sr}(p>0.05)$ in S. cucullata. While for T. clavigera, there are significant differences $(p<0.05)$ in $\mathrm{Pb}, \mathrm{Zn}$ and Co concentrations among locations in the soft tissue and $\mathrm{Zn}, \mathrm{Se}$ and $\mathrm{Sr}$ in the shell. However, no significant differences were found for all studied metals among locations in the operculum. The interspatial distribution on metals shows no similar pattern among body parts.

Table 2. Concentrations of $\mathrm{Pb}, \mathrm{Cd}, \mathrm{Cu}, \mathrm{Zn}, \mathrm{Mn}, \mathrm{Co}, \mathrm{Se}$ and $\mathrm{Sr}\left(\mu \mathrm{g} \mathrm{g}{ }^{-1}\right.$ dry weight) in soft tissue, operculum and shell of $S$. cucullata, T. clavigera and $N$. chameleon (mean and standard deviation) from East Johore coastal waters

\begin{tabular}{|c|c|c|c|c|c|c|c|c|}
\hline Site & $\mathbf{P b}$ & Cd & $\mathrm{Cu}$ & $\mathbf{Z n}$ & Mn & Co & Se & $\mathbf{S r}$ \\
\hline \multicolumn{9}{|c|}{ S. cucullata } \\
\hline 1 & $1.19 \pm 0.17$ & $1.79 \pm 0.26$ & $211.5 \pm 35.27$ & $2253.1 \pm 459.6$ & $10.92 \pm 7.17$ & $0.23 \pm 0.08$ & $3.05 \pm 0.30$ & $89.37 \pm 86.4$ \\
\hline 2 & $0.98 \pm 1.31$ & $2.49 \pm 0.36$ & $226.2 \pm 47.70$ & $1114.7 \pm 247.0$ & $4.39 \pm 2.79$ & $0.08 \pm 0.02$ & $3.85 \pm 0.95$ & $49.02 \pm 11.4$ \\
\hline 3 & $0.85 \pm 0.38$ & $2.24 \pm 0.13$ & $256.4 \pm 12.7$ & $5277.3 \pm 843.3$ & $4.03 \pm 1.58$ & $0.42 \pm 0.05$ & $6.83 \pm 1.20$ & $45.89 \pm 1.13$ \\
\hline 4 & $0.35 \pm 0.19$ & $4.37 \pm 0.71$ & $212.4 \pm 29.3$ & $5190.6 \pm 1510.0$ & $5.30 \pm 2.54$ & $0.29 \pm 0.05$ & $6.46 \pm 0.20$ & $168.7 \pm 161.4$ \\
\hline 5 & $1.02 \pm 0.22$ & $2.84 \pm 0.39$ & $166.1 \pm 54.5$ & $810.3 \pm 245.1$ & $5.12 \pm 2.31$ & $0.20 \pm 0.05$ & $3.08 \pm 0.17$ & $80.65 \pm 38.0$ \\
\hline Average & $0.88 \pm 0.32$ & $2.75 \pm 0.99$ & $214.52 \pm 32.57$ & $2929 \pm 2171$ & $5.95 \pm 2.83$ & $0.25 \pm 0.13$ & $4.65 \pm 1.85$ & $86.72 \pm 49.61$ \\
\hline \multicolumn{9}{|c|}{ T. clavigera } \\
\hline & Soft tissue & & & & & & & \\
\hline 1 & $0.43 \pm 0.06$ & $3.73 \pm 1.40$ & $192.2 \pm 120.0$ & $308.8 \pm 79.02$ & $2.86 \pm 0.49$ & $0.29 \pm 0.30$ & $5.88 \pm 2.02$ & $34.98 \pm 6.55$ \\
\hline 3 & $0.21 \pm 0.02$ & $4.15 \pm 1.24$ & $148.1 \pm 58.9$ & $868.8 \pm 262.3$ & $4.30 \pm 0.40$ & $0.31 \pm 0.08$ & $7.69 \pm 1.08$ & $48.71 \pm 9.71$ \\
\hline 4 & $0.21 \pm 0.06$ & $4.65 \pm 1.82$ & $157.3 \pm 71.6$ & $374.8 \pm 106.0$ & $6.06 \pm 3.71$ & $0.09 \pm 0.07$ & $5.19 \pm 3.08$ & $34.91 \pm 30.02$ \\
\hline 5 & $0.49 \pm 0.41$ & $5.00 \pm 1.50$ & $215.9 \pm 86.1$ & $238.1 \pm 8.08$ & $6.60 \pm 2.62$ & $0.10 \pm 0.02$ & $7.16 \pm 1.56$ & $42.11 \pm 11.01$ \\
\hline \multirow[t]{2}{*}{ Average } & $0.33 \pm 0.15$ & $4.38 \pm 0.56$ & $178.36 \pm 31.42$ & $447.61 \pm 286.27$ & $4.96 \pm 1.71$ & $0.20 \pm 0.12$ & $6.48 \pm 1.15$ & $40.18 \pm 6.62$ \\
\hline & Operculum & & & & & & & \\
\hline 1 & $0.63 \pm 0.16$ & $0.16 \pm 0.11$ & $13.64 \pm 1.53$ & $15.83 \pm 4.71$ & $9.10 \pm 4.38$ & $0.09 \pm 0.03$ & $34.97 \pm 8.63$ & $10.26 \pm 1.97$ \\
\hline 3 & $0.71 \pm 0.08$ & $0.19 \pm 0.01$ & $23.73 \pm 10.92$ & $26.83 \pm 3.92$ & $12.33 \pm 2.66$ & $0.22 \pm 0.03$ & $53.73 \pm 8.72$ & $18.29 \pm 10.29$ \\
\hline 4 & $0.43 \pm 0.03$ & $0.23 \pm 0.14$ & $19.93 \pm 3.60$ & $28.29 \pm 8.13$ & $9.03 \pm 2.50$ & $0.07 \pm 0.03$ & $39.19 \pm 10.7$ & $7.74 \pm 2.00$ \\
\hline 5 & $1.04 \pm 1.04$ & $0.39 \pm 0.03$ & $20.37 \pm 3.51$ & $25.09 \pm 5.94$ & $9.26 \pm 2.02$ & $0.10 \pm 0.02$ & $31.86 \pm 7.79$ & $10.92 \pm 7.85$ \\
\hline \multirow[t]{2}{*}{ Average } & $0.70 \pm 0.26$ & $0.24 \pm 010$ & $19.42 \pm 4 . .21$ & $24.01 \pm 5.61$ & $9.93 \pm 1.60$ & $0.12 \pm 0.07$ & $39.93 \pm 9.67$ & $11.80 \pm 4.54$ \\
\hline & Shell & & & & & & & \\
\hline 1 & $0.19 \pm 0.03$ & $0.29 \pm 0.17$ & $1.47 \pm 0.75$ & $2.70 \pm 0.62$ & $1.63 \pm 0.65$ & $0.70 \pm 0.07$ & $8.33 \pm 3.63$ & $1343.6 \pm 39.04$ \\
\hline 3 & $0.14 \pm 0.01$ & $0.36 \pm 0.51$ & $1.63 \pm 0.70$ & $3.90 \pm 0.66$ & $0.94 \pm 0.08$ & $0.58 \pm 0.02$ & $3.89 \pm 0.94$ & $1216.9 \pm 30.02$ \\
\hline 4 & $0.17 \pm 0.10$ & $2.24 \pm 3.65$ & $3.06 \pm 1.65$ & $6.07 \pm 2.20$ & $0.85 \pm 0.80$ & $0.58 \pm 0.13$ & $2.78 \pm 0.11$ & $1306.9 \pm 126.2$ \\
\hline 5 & $0.16 \pm 0.04$ & $0.17 \pm 0.03$ & $3.20 \pm 1.94$ & $3.65 \pm 0.59$ & $0.59 \pm 0.12$ & $0.57 \pm 0.05$ & $2.22 \pm 0.44$ & $1258.3 \pm 62.01$ \\
\hline Average & $0.16 \pm 0.02$ & $0.77 \pm 0.02$ & $2.33 \pm 0.99$ & $4.08 \pm 0.91$ & $1.00 \pm 1.43$ & $0.61 \pm 0.45$ & $4.31 \pm 0.06$ & $1281.42 \pm 2.77$ \\
\hline \multicolumn{9}{|c|}{ N. chameleon } \\
\hline & Soft tissue & & & & & & & \\
\hline 1 & $3.98 \pm 1.88$ & $0.36 \pm 0.28$ & $86.33 \pm 22.25$ & $62.61 \pm 8.83$ & $29.14 \pm 8.83$ & $0.45 \pm 0.13$ & $3.41 \pm 0.8$ & $223.7 \pm 141.1$ \\
\hline 2 & $3.92 \pm 0.87$ & $0.83 \pm 0.45$ & $37.98 \pm 9.57$ & $61.42 \pm 11.39$ & $21.67 \pm 6.67$ & $0.32 \pm 0.09$ & $3.10 \pm 0.53$ & $151.0 \pm 60.29$ \\
\hline 3 & $2.24 \pm 0.74$ & $2.35 \pm 4.78$ & $16.06 \pm 14.51$ & $63.39 \pm 12.14$ & $22.92 \pm 6.82$ & $0.34 \pm 0.08$ & $2.45 \pm 0.97$ & $143.7 \pm 73.99$ \\
\hline 4 & $2.62 \pm 0.29$ & $0.23 \pm 0.16$ & $19.93 \pm 1.88$ & $69.33 \pm 9.52$ & $17.28 \pm 6.44$ & $0.29 \pm 0.02$ & $4.24 \pm 0.88$ & $127.8 \pm 36.02$ \\
\hline 5 & $3.37 \pm 0.95$ & $15.59 \pm 22.41$ & $55.59 \pm 11.86$ & $62.91 \pm 16.93$ & $20.90 \pm 2.89$ & $0.30 \pm 0.04$ & $3.29 \pm 0.98$ & $71.84 \pm 32.70$ \\
\hline Average & $3.22 \pm 0.78$ & $3.87 \pm 6.61$ & $43.18 \pm 28.81$ & $63.93 \pm 3.10$ & $22.38 \pm 4.32$ & $0.34 \pm 0.06$ & $3.30 \pm 0.64$ & $143.61 \pm 54.48$ \\
\hline
\end{tabular}


Table 2 (cont'd). Concentrations of $\mathrm{Pb}, \mathrm{Cd}, \mathrm{Cu}, \mathrm{Zn}, \mathrm{Mn}, \mathrm{Co}, \mathrm{Se}$ and $\mathrm{Sr}\left(\mu \mathrm{g} \mathrm{g}^{-1}\right.$ dry weight) in soft tissue, operculum and shell of S. cucullata, T. clavigera and N. chameleon (mean and standard deviation)

from East Johore coastal waters

\begin{tabular}{ccccccccr}
\hline Site & $\mathbf{P b}$ & $\mathbf{C d}$ & $\mathbf{C u}$ & $\mathbf{Z n}$ & $\mathbf{M n}$ & $\mathbf{C o}$ & $\mathbf{S e}$ & $\mathbf{S r}$ \\
\hline & & & & & & & & \\
1 & Operculum & & & & & & \\
2 & $1.02 \pm 0.23$ & $0.05 \pm 0.02$ & $1.14 \pm 0.36$ & $2.49 \pm 1.81$ & $4.52 \pm 1.29$ & $0.32 \pm 0.08$ & $1.40 \pm 0.20$ & $2485.7 \pm 128.5$ \\
3 & $0.95 \pm 0.27$ & $0.05 \pm 0.02$ & $0.49 \pm 0.56$ & $2.07 \pm 1.05$ & $2.76 \pm 0.65$ & $0.39 \pm 0.04$ & $1.22 \pm 0.38$ & $2164.7 \pm 131.6$ \\
4 & $1.56 \pm 1.28$ & $0.57 \pm 0.87$ & $1.12 \pm 0.86$ & $3.97 \pm 1.82$ & $6.47 \pm 1.83$ & $0.52 \pm 0.12$ & $1.06 \pm 0.67$ & $2446.1 \pm 245.1$ \\
5 & $1.57 \pm 0.47$ & $0.06 \pm 0.03$ & $0.90 \pm 0.10$ & $4.42 \pm 2.09$ & $6.65 \pm 2.62$ & $0.43 \pm 0.02$ & $1.81 \pm 0.18$ & $2500.4 \pm 93.77$ \\
Average & $1.19 \pm 0.23$ & $0.03 \pm 0.01$ & $1.92 \pm 0.39$ & $3.56 \pm 3.10$ & $8.77 \pm 2.78$ & $0.44 \pm 0.02$ & $1.56 \pm 0.55$ & $2445.0 \pm 81.41$ \\
& $1.37 \pm 0.16$ & $0.16 \pm 0.23$ & $2.93 \pm 4.12$ & $4.83 \pm 3.10$ & $6.40 \pm 2.23$ & $0.42 \pm 0.07$ & $1.48 \pm 0.33$ & $2355.28 \pm 151.6$ \\
& & & & & & & \\
1 & Shell & & & & & & \\
2 & $0.63 \pm 0.30$ & $0.03 \pm 0.01$ & $1.66 \pm 2.30$ & $5.82 \pm 2.77^{c}$ & $8.75 \pm 3.80$ & $0.89 \pm 0.15$ & $0.76 \pm 0.21$ & $1676.6 \pm 186.8$ \\
3 & $1.12 \pm 2.11$ & $3.29 \pm 8.98$ & $1.78 \pm 3.10$ & $5.52 \pm 6.04$ & $4.77 \pm 1.52$ & $0.80 \pm 0.11$ & $1.09 \pm 0.22$ & $1319.0 \pm 149.4$ \\
4 & $0.35 \pm 0.23$ & $1.58 \pm 2.18$ & $0.83 \pm 0.91$ & $2.94 \pm 0.95$ & $8.11 \pm 4.20$ & $0.74 \pm 0.10$ & $1.11 \pm 0.27$ & $1199.3 \pm 99.27$ \\
5 & $0.15 \pm 0.05$ & $1.48 \pm 3.13$ & $0.25 \pm 0.15$ & $3.16 \pm 1.16$ & $5.06 \pm 1.65$ & $0.66 \pm 0.11$ & $1.04 \pm 0.32$ & $1091.8 \pm 65.51$ \\
Average & $0.24 \pm 0.07$ & $0.93 \pm 0.99$ & $1.24 \pm 1.35$ & $3.66 \pm 2.83$ & $9.16 \pm 3.85$ & $0.61 \pm 0.07$ & $0.94 \pm 0.16$ & $1134.8 \pm 65.64$ \\
& $0.50 \pm 0.39$ & $1.46 \pm 1.19$ & $1.15 \pm 0.62$ & $4.22 \pm 1.36$ & $7.17 \pm 2.09$ & $0.74 \pm 0.11$ & $0.99 \pm 0.14$ & $1284.29 \pm 235.4$ \\
\hline
\end{tabular}

In $N$. chameleon, significant differences $(p<0.05)$ among concentrations of all studied metals between locations were found in the soft tissue of $N$. chameleon, except $\mathrm{Cd}$. There were significant differences $(p<0.05)$ between $\mathrm{Pb}, \mathrm{Cd}, \mathrm{Mn}, \mathrm{Co}, \mathrm{Se}$ and $\mathrm{Sr}$ concentrations in operculum of $N$. chameleon among sampling locations. No correlation was found for $\mathrm{Cu}$ and $\mathrm{Zn}$. Significant differences $(p<0.05)$ were found only for $\mathrm{Zn}, \mathrm{Mn}$ and Co concentrations in shell of $N$. chameleon between sampling locations.

\section{Interspecies}

A point to be made on the significance of accumulated trace metal concentrations among species is the potential for metals to be transferred along food chains. The elevated concentration of metals found in $T$. clavigera may be the result of biomagnification transfer from the rock oysters on which they feed while for N. chameleon, it might be derived from their herbivorous feeding behaviour on algae on rocks which they graze. Predatory gastropod, $T$. clavigera and prey $S$. cucullata have been acknowledged to have food chain relationships by several studies [8,9]. Therefore, the levels of heavy metals in this predatory organism could be derived as a result of transfer from the rock oysters $[10,11]$. It may obtain significant amounts of metals from the dietary source if the prey has high metals content. Also, field evidence suggests that dietary exposure is the dominant route for Thais to accumulate metals [12]. In this case, it is concluded that food ( $S$. cucullata) probably is the most important source for metals in $T$. clavigera.

The metal accumulation pattern of $\mathrm{Zn}$ and $\mathrm{Cu}$ within studied organisms presented a decreasing pattern of $S$. cucullata $>$ T. clavigera $>N$. chameleon (Table 2). $\mathrm{Zn}$ and $\mathrm{Cu}$ concentrations in the studied bivalve are much higher than gastropods by about $6-27$ times. $\mathrm{Zn}$ and $\mathrm{Cu}$ are emphasized as they evidently proved to being essential in living organisms in the functioning of metabolic processes and associated with many enzymatic proteins functions [13-14]. Filter feeders are acknowledged to have high proportion of permeable surfaces and thus have been proven to take up metals at high rates [15].

T. clavigera in this study evidently accumulates the highest concentration of $\mathrm{Cd}$ and Se with the sequence of $T$. clavigera $>S$. cucullata $>N$. chameleon. The high concentration of $\mathrm{Cd}$ within $T$. clavigera is well documented by several studies. This neogastropod is able to accumulate $\mathrm{Cd}$ very efficiently from the food without any noxious effect [16], and even in unpolluted waters, neogastropod accumulate $\mathrm{Cd}$ at high concentration. Se metal is one of interest because it is classified as both an essential elements for organisms [17] and toxic at elevated levels [18]. It is suggested that this metal has a high potential of biomagnifications during transfer to top predator. Studies by Underwood [19] had shown that there were differences in the type of feeding between grazing species and type of food ingested by these species as well as differences in digestion and feeding mechanisms. 
The result highlighted that $\mathrm{Sr}$, which is considered as a non-essential element, is distributed differently in soft tissue of $N$. chameleon compared with the other elements (Table 2). Distribution of Sr within soft tissue in other literature was sparse as they commonly focused on the incorporation of $\mathrm{Sr}$ and $\mathrm{Mg}$ together with other trace metals as well within the shell [20,21]. Despite a few differences, the pattern of metal occurrences is in agreement with studies by Ruelaz-Inzunza \& Paez-Osuna [22] and Amin et al. [23] that indicate approximately the same pattern of essential metals enrichment.

\section{Inter tissue}

Referring to Table 2, metal accumulations in soft tissue, operculum and shell of $T$. clavigera vary in magnitude but generally showed similar patterns of accumulation for certain metals. The $\mathrm{Zn}$ and $\mathrm{Cu}$ accumulation pattern was in the sequence of soft tissue > operculum > shell; $\mathrm{Cd}$ soft tissue > shell > operculum; $\mathrm{Se}, \mathrm{Mn}$ and $\mathrm{Pb}$ operculum > soft tissue > shell; and $\mathrm{Co}$ and $\mathrm{Sr}$ shell > soft tissue > operculum. While in N. chameleon, $\mathrm{Pb}, \mathrm{Cd}, \mathrm{Zn}$ and $\mathrm{Mn}$ concentrations was found in the sequence of soft tissue > operculum > shell; for $\mathrm{Cu}$ and $\mathrm{Se}$, soft tissue > shell > operculum; Co shell > operculum > soft tissue; and Sr operculum > shell > soft tissue. The results indicated that most metals were accumulated in soft tissue compared to operculum and shell.

In order to evaluate the relationship between the operculum, shell and soft tissue with the concentrations of the metals studied, the ratio in body parts of T. clavigera and $N$. chameleon was computed (Table 3). Values of operculum to tissue ratio (OTR) and shell to tissue (STR) higher than unity in T. clavigera indicate that operculum had higher affinities for $\mathrm{Pb}, \mathrm{Mn}$ and Se while shell had higher affinities for $\mathrm{Co}$ and $\mathrm{Sr}$. Meanwhile, values of OTR and STR higher than unity in $N$. chameleon display that operculum and shell had similar higher affinities for Co and $\mathrm{Sr}$, with addition of $\mathrm{Cd}$ for shells. The high concentration of these metals in operculum and shell could probably be due to the fact that the crystalline structures of the operculum and shell matrix had a higher capacity for incorporation in the soft tissue.

Table 3. Mean ratios and standard deviation of operculum metals to soft tissue metals (OTR) and shell metals to soft tissue metals (STR) in T. clavigera and N. chameleon

\begin{tabular}{lccccccccc}
\hline Species & Ratio & Pb & Cd & Cu & Zn & Mn & Co & Se & Sr \\
\hline T. clavigera & OTR & 2.28 & 0.05 & 0.11 & 0.07 & 2.23 & 0.69 & 6.23 & 0.29 \\
& & \pm 0.85 & \pm 0.02 & \pm 0.04 & \pm 0.03 & \pm 0.92 & \pm 0.29 & \pm 1.36 & \pm 0.07 \\
& & & & & & & & & \\
& STR & 0.56 & 0.17 & 0.01 & 0.01 & 0.25 & 4.11 & 0.69 & 32.68 \\
& & \pm 0.22 & \pm 0.21 & \pm 0.01 & \pm 0.01 & \pm 0.22 & \pm 2.28 & \pm 0.49 & \pm 6.39 \\
N. chameleon & & & & & & & & & \\
& & 0.46 & 0.15 & 0.06 & 0.08 & 0.29 & 1.29 & 0.45 & 18.98 \\
& & \pm 0.19 & \pm 0.12 & \pm 0.04 & \pm 0.05 & \pm 0.12 & \pm 0.34 & \pm 0.04 & \pm 9.14 \\
& STR & 0.15 & 2.24 & 0.03 & 0.07 & 0.32 & 2.20 & 0.31 & 9.78 \\
& & \pm 0.09 & \pm 2.84 & \pm 0.02 & \pm 0.02 & \pm 0.08 & \pm 0.21 & \pm 0.09 & \pm 3.39 \\
\hline
\end{tabular}

\section{Permissible limits}

To safeguard public health, maximum acceptable concentrations of toxic contaminants have been established in various countries, including Malaysia. Most of safety levels established was expressed on a wet weight basis. Therefore, metal concentrations for each species in this study have been calculated into wet weight basis using conversion factor for comparison with permissible limits set by Malaysia and other different countries (Table 4). 
Table 4. Maximum permissible limits on heavy metals (in $\mu \mathrm{g} \mathrm{g}^{-1}$ ) for food safety set by different countries based on wet weight basis of soft tissue

\begin{tabular}{|c|c|c|c|c|}
\hline & $\mathbf{P b}$ & Cd & $\mathbf{C u}$ & Zn \\
\hline \multicolumn{5}{|l|}{ Shellfish molluscs } \\
\hline European Community & $1.5^{[24]}$ & $1^{[24]}$ & & \\
\hline Hong Kong & $6^{[25]}$ & $2^{[25]}$ & \multirow{2}{*}{\multicolumn{2}{|c|}{$30^{[27]}$}} \\
\hline Australia & $2^{[26]}$ & $2^{[26]}$ & & \\
\hline USA & $1.7^{[28]}$ & $3.7^{[28]}$ & & \\
\hline Malaysia & $2^{[29]}$ & $1^{[29]}$ & $30^{[29]}$ & \\
\hline \multicolumn{5}{|l|}{ This study } \\
\hline S. cucullata & 0.24 & 0.41 & $34.69 *$ & $332.98 *$ \\
\hline T. clavigera & 0.13 & $1.10^{*}$ & $32.52 *$ & 73.70 \\
\hline N. chameleon & 0.77 & 0.55 & 8.18 & 14.34 \\
\hline \multicolumn{5}{|c|}{$\begin{array}{l}{ }^{[24]} \text { European Community (CE, 2006), }{ }^{[25]} \text { Hong Kong Environmental Protection Departme } \\
\text { (HKEPD, 1997), }{ }^{[26]} \text { Food standards Australia New Zealand Authority (FSANZ, } 1996 \\
\text { [27] Australian Government, 2006, }{ }^{[28]} \text { Food and Drug Administration of the United Stat } \\
\text { (USFDA, 1990), }{ }^{[29]} \text { Malaysian Food Regulation Fourteen Schedule (1985), *Values th } \\
\text { exceed the permissible limits set by Malaysian Food Regulation Fourteen Schedule }\end{array}$} \\
\hline
\end{tabular}

The results of this study indicate that $\mathrm{Zn}$ concentrations in rock oyster $S$. cucullata are higher than the food security limits. Thus, S. cucullata is considered unsafe for consumption in conjunction with high Zn concentration, as concentrations are approximately three times higher than safety limits. The high levels of $\mathrm{Zn}$ may pose a serious problem as S. cucullata is one of important food source that consumed in Malaysia [30].

\section{Conclusion}

The present work has provided a synoptic survey of metals distribution in selected species in rocky shore areas along the east Johor coastal waters. The bivalve mollusc, $S$. cucullata and the two gastropod molluscs $T$. clavigera and $N$. chameleon possessed high potential as cosmopolitan bioindicators for trace metal. These species have the necessary prerequisites of bioindicators: they are easy to identify and to sample, are available throughout the year, and are widely abundant in almost all rocky shore areas.

Interspecies variation among studied species indicated that certain species are proven to be good bioindicators of certain metals. Inter-tissue variation of metal concentrations lead to the conclusion that essential metals like $\mathrm{Zn}, \mathrm{Cu}$, $\mathrm{Se}$ and $\mathrm{Mn}$ are highly accumulated in soft tissue compare with operculum and shell as a result of having an important role in metabolism. Ratio calculation on body parts indicates high affinities of certain metals in operculum and shell of $T$. clavigera and $N$. chameleon, indicating that these body parts are also able to serve as bioindicator tissue as an alternative to the commonly used soft tissue. Particular significant metal pair correlation indicates that metal accumulation in specific body part might be affected by the other metal in the pairing. Consistent enrichment of essential metals over non-essential metals is also observed.

From the present status, it may be concluded that $S$. cucullata is unsafe for human consumption in conjunction with high Zn concentration, which was approximately three times higher than the safety limits set by Malaysian Food Regulations 1985 Fourteen Schedule and also with the limits set by other countries. Due to the importance of oyster as seafood and its ability to accumulate pollutants, sustained and continued monitoring of metals in S. cucullata may be important in avoiding future health risk issues related to their consumption.

\section{References}

1. Zhou, Q., Zhang, J., Fu, J., Shi, J. and Jiang, G. (2008). Biomonitoring: An appealing tool for assessment of metal pollution in the aquatic ecosystem. Analytica Chimica Acta, 606 (2): 135 - 150. 
2. Shazili, N. A. (2004). Metals in the Marine Environment. KUSTEM Inaugural Lecture. Kolej Universiti Sains dan Teknologi Malaysia (KUSTEM).

3. Goldberg, E. D. (1978). The mussel watch - A first step in global marine monitoring. Marine Pollution Bulletin, 6(7): $111-114$.

4. Legierse, K. C. H. M., Sijm, D. T. H. M., Leeuwen, C. J. V., Seinen, W. and Hermens, J. L. M. (1998). Bioconcentration kinetics of chlorobenzenes and the organophosphorus pesticide chloration in the pond snail Lymneaestagnalis- a comparison with the guppy Poeciliareticulata. Aquatic Toxicology, 41:301-323.

5. Yap, C. K., Ismail, A., Edward, F. B., Tan, S. G. and Siraj, S. S. (2006). Use of different soft tissues of Perna viridis as biomonitors of bioavailability and contamination by heavy metals $(\mathrm{Cd}, \mathrm{Cu}, \mathrm{Fe}, \mathrm{Pb}, \mathrm{Ni}$ and $\mathrm{Zn})$ in a semi- enclosed intertidal water, the Johore Straits. Toxicological and Environmental Chemistry, 88(4): 683 695.

6. Fuad, M. M., Shazili, N. A. M and Faridah, M. (2013). Trace metals and rare earth elements in Rock Oyster Saccostrea cucullata along the east coast of Peninsular Malaysia. Aquatic Ecosystem Health and Management, 16(1): $78-87$.

7. Shazili, N. A. M, Azlisham, M. and Vedamanikam, V. J., 2009. Concentrations of cadmium, manganese, copper, zinc and lead in the tissues of the oyster (Crassostrea iradalei) obtained from Setiu Lagoon, Terengganu, Malaysia. Toxicological and Environmental Chemistry, 91(2): 251 - 258.

8. Blackmore, G. (2000). Field evidence of metal transfer from invertebrate prey to an intertidal predator, Thais clavigera (Gastropoda: Muricidae). Estuarine, Coastal and Shelf Science, 51(2): 127 - 139.

9. Blackmore, G. and Wang, W.-X. (2004). The transfer of cadmium, mercury, methylmercury, and zinc in an intertidal rocky shore food chain. Journal of Experimental Marine Biology and Ecology, 307(1): 91 - 110.

10. Jeng, M-. S., Jeng, W-. L., Hung, T-. C., Yeh, C-. Y., Tseng, R-. J., Meng, P-. J. and Han, B-.C. (2000). Mussel Watch: A review of $\mathrm{Cu}$ and other metals in various marine organisms in Taiwan, 1991-98. Environmental Pollution, 110(2): $207-215$.

11. Shazili, N. A., Husain, M. L., Rashid, M. K. A., Yaakob, R., Shamsuddin, A. A. and Razali, M. S., (1995). Trace metal contents in the fish and bivalves from East Coast Malaysia, International Seminar on Marine Fisheries Environment 1995. Eastern Marine Fisheries Development Center and Japan International Cooperation Agency, Rayong, Thailand, pp. 199-208.

12. Blackmore, G. and Morton, B. (2001). The interpretations of body trace metal concentrations in Neogastropods from Hong Kong. Marine Pollution Bulletin, 42(11): 1161 - 1168.

13. Amiard, J. C., Triquet, C. A., Charbonnier, L., Mesnil, A., Rainbow, P. S., and Wang, W. (2008). Bioaccessibility of essential and non-essential metals in commercial shellfish from Western Europe and Asia. Food and Chemical Toxicology, 46(6): 2010 - 2022.

14. Yap, C. K., Hisyam, M. N. D., Edward, F. B., Cheng, W. H. and Tan, S. G. (2010). Concentrations of heavy metal in different parts of the gastropod, Faunus ater, collected from intertidal areas of Peninsular Malaysia. Pertanika Journal of Tropical Agricultural Science, 33(1): 45 - 60.

15. Blackmore, G. (2001). Interspecific variation in heavy metal body concentrations in Hong Kong marine invertebrates. Environmental Pollution, 114(3): 303 - 311.

16. Cheung, M.-S., Fok, E. M. W., Ng, T. Y. T., Yen, Y. F. and Wang, W. X. (2006). Subcellular cadmium distribution, accumulation and toxicity in a predatory gastropod, Thais clavigera, fed different prey. Environmental Toxicology and Chemistry, 25: 174-181.

17. Jolley, D. F., Maher, W. A. and Kyd, J. (2004). Selenium accumulation in the cockle Anadara trapezia. Environmental Pollution, 132: 203 - 212.

18. Peters, G. M., Maher, G. M., Krikowa, F., Roach, A. C., Jeswani, H. K., Barford, J. P., Gomes, V. G. and Reible, D. D. (1999). Selenium in sediments, pore waters and benthic infauna of Lake Macquire, New South Wales, Australia. Marine Environmental Research, 47: 491 - 508.

19. Underwood, A. J. (1974). The reproduce cycles and geographical distribution of some common Eastern Australian prosobranch (Mollusca: Gastropoda). Australian Journal of Marine and Freshwater Research, 25: $63-88$.

20. Cravo, A., Foster, P., Ameida, C., Company, R., Cosson, R. P. and Bebianno, M. J. (2007). Metals in the shell of Bathymodiolus azoricus from a hydrothermal vent site on the Mid-Atlanctic Ridge. Environment International, 33: $609-615$. 
21. Foster, P. and Cravo, A. (2003). Minor elements and trace elements in the shell of marine gastropods from a shore in tropical East Africa. Water, Air and Soil Pollution, 145: 53 - 65.

22. Ruelas-Inzunza, J. R. and Paez-Osuna, F. (2000). Comparative bioavailability of trace metals using three filterfeeder organisms in a subtropical coastal environment (Southeast Gulf of California). Environmental Pollution, 107: $437-444$.

23. Amin, B., Ismail, A., Arshad, A., Yap, C.K. and Kamarudin, M.S. (2006). A comparative study of heavy metal concentrations Neritalineata from the intertidal zone between Dumai, Indonesia and Johor, Malaysia. Journal of Coastal Development, 10: 19-32.

24. Commission Europeénne, CE (2006). Regulation (CE) No. 1881/2006 of 19 December 2006 setting maximum levels for certain contaminants in foodstuffs. Official Journal of the European Union, L 364/5 du 20 December 2006.

25. Hong Kong Environmental Protection Department, (1997). Marine water quality in Hong Kong in 1997. Government Printer Hong Kong.

26. Food Standards Australia New Zealand Authority, FSANZ (1996). Food Standard for Australia and New Zealand.

27. Australian Government (2006). The Maximum Residual Limit Standard.

28. Food and Drug Administration of the United States, USFDA (1990). US Food and Drug Administration Shellfish Sanitation Branch, Washington, DC.

29. Malaysian Food Regulation (1985). Fourteenth Schedule Malaysian law on food and drugs. Malaysian Law Publishers.

30. Yap, C. K., Mohd Ruszaidi, S. and Cheng, W. H. (2010). Different tissues of rock oyster Saccostrea cucullata as biomonitors of trace metal bioavailabilities in the Penang coastal waters, Malaysia. Research Journal of Chemistry and Environment, 14(3): $17-21$. 